\title{
Modelling Toxin-Producing Algae in the Coastal Waters of Nigeria
}

\author{
M. O. Kadiri' ${ }^{1}$, T. E. Unusiotame-Owolagba ${ }^{2}$ \\ ${ }^{1}$ Department of Plant Biology \& Biotechnology, University of Benin, Benin City, Nigeria \\ ${ }^{2}$ Department of Marine Environment \& Pollution Control, Nigeria Maritime University, Okerenkoko, Nigeria \\ Email:mokadiri12@gmail.com
}

How to cite this paper: Kadiri, M.O. and Unusiotame-Owolagba, T.E. (2020) Modelling Toxin-Producing Algae in the Coastal Waters of Nigeria. Journal of Water Resource and Protection, 12, 74-92. https://doi.org/10.4236/jwarp.2020.121005

Received: November 27, 2019

Accepted: January 13, 2020

Published: January 16, 2020

Copyright (c) 2020 by author(s) and Scientific Research Publishing Inc. This work is licensed under the Creative Commons Attribution International License (CC BY 4.0).

http://creativecommons.org/licenses/by/4.0/

\section{(c) (i) Open Access}

\begin{abstract}
This research describes the development and application of an empirical model for toxin-producing algae developed from time series of cell abundance coupled with concurrent measurements of environmental variables in Nigerian coast, Gulf of Guinea. A Generalized Linear Model was formulated to predict the population size of Cyanophyta, Oscillatoria, Dinophyta, total phytoplankton abundance and toxic algae, for four different months in a year, namely March (dry-wet period), July (wet period), October (wet-dry period) and January (dry period), using 12 input variables, namely $\mathrm{pH}$, salinity, $\mathrm{PO}_{4}$, $\mathrm{NO}_{3}, \mathrm{Fe}$, water temperature, $\mathrm{DO}$, turbidity, $\mathrm{Si}, \mathrm{SO}_{4}$ and location determined by Latitude and Longitude coordinates, with data collected from 53 locations. The interactive effects of silicate and iron were also modeled to elicit effect of these nutrients on the density and occurrence of toxic algae/phytoplankton and total phytoplankton abundance. The model gives a very good fit for the data and the results reveal the influence of season, location and nutrients on the variation in the abundance of total phytoplankton abundance and the toxic form abundance. In the wet season and dry seasons, surface and stem plots for total phytoplankton abundance and toxic algae abundance were noticeably dissimilar, with the Lagos axis of the Atlantic Ocean having significantly high total phytoplankton abundance in the wet season and abundant toxic algae in the south-south locations of Cross River and Akwa Ibom. Ondo and Ogun axes of the Atlantic Ocean had significantly high abundance of the toxic algae in the dry season. In the dry-wet and wet-dry seasons, the surface and stem plots for total phytoplankton abundance and toxic algae abundance were similar. There was significant abundance of toxic algae in the south-west locations. Specifically, Ondo and Ogun in the south-west had significantly high total phytoplankton and toxic algae abundance in the dry-wet season.
\end{abstract}




\section{Keywords}

Toxic Algae, Modelling, Africa, Gulf of Guinea

\section{Introduction}

$\mathrm{HABs}$ incidence and mass occurrences of toxic algae have increased in recent years, in frequency, extent and geographic distribution [1] [2] [3]. Harmful algal blooms are of global concern and have caused severe ecological, economic and human health damages worldwide [4] [5] [6] [7] [8]. These blooms are triggered by cultural eutrophication or nutrient pollution [4] [8] [9] [10] [11] [12].

It is estimated that one-quarter of Nigerian population live in the coastal zone represented by nine states [13]. An increase in human coastal populations, industrialization, and the intensification of agriculture have elevated the supply of macronutrients such as nitrogen $(\mathrm{N})$ and phosphorus $(\mathrm{P})$ to coastal waters [14]. The Nigerian coast contains a diverse group of phytoplankton of different genera and species [15]. The phytoplankton will bloom under favourable nutrient conditions while a relatively few species of phytoplankton produce biotoxins under certain ecological conditions.

The toxin produced can remain inside the algal cells (intracellular toxins), or they may be released into the surrounding water (extracellular toxins) during active algal growth or when algal cells lyse [16]. Toxin producing phytoplankton can cause harm to aquatic and terrestrial animals. These toxins directly or indirectly enter aquatic and terrestrial animals and bioaccumulate, biotransfer and biomagnify through food chains and webs [10] [16] [17] [18]. Algal toxins can also be lethal to humans. It was reported that worldwide, algal toxins of all types may be responsible for as many as 60,000 intoxication incidents per year [19]. They are responsible for the production of certain poisoning syndromes in humans. The respective poisoning syndromes have been named paralytic, diarrhetic, neurotoxic, amnesic, and azaspiracid shellfish poisoning (PSP, DSP, NSP, ASP, and AZP respectively) and ciguatera fish poisoning (CFP) [20].

Earlier preliminary reports by [21] [22] [23] [24] revealed the presence of potentially toxic phytoplankton in the Nigerian coastal waters. More recently, Zendong et al. [25] reported the presence of algal toxin in the coastal waters of Nigeria. Although there are no records of human illness and massive aquatic animals and fish kills in Nigerian coastal waters, the presence of toxins producing species of phytoplankton implies the possibilities of its occurrence. There is however, no report of mathematical modelling of toxic phytoplankton in the coastal waters of Nigeria.

Mathematical modelling is a valuable tool to explore the features of the interaction between certain environmental variables and toxin producing phytoplankton. It is vital to use this tool to predict the presence of toxin-producing phytoplankton in the Nigerian coast. This could serve as a precautionary man- 
agement tool, considering the reliance of its increasing population on marine ecosystems.

Several modelling frameworks have been used in HAB and HAB-related study worldwide. Chattopadhyay et al. [26] proposed a mathematical framework to show the relationship between toxin phytoplankton and zooplankton and concluded that toxin released by toxigenic species play a significant role in bloom termination by reducing zooplankton grazing pressure. In the same vain $\mathrm{Pal}$ et al. [27] proposed a nutrient-phytoplankton-zooplankton model and it was revealed in their result that the concentration of toxin that surpasses a threshold level dampens phytoplankton-zooplankton population oscillations. Meanwhile, Chakraborty et al. [28] used a nutrient-phytoplankton model approach to explore the dynamics of seasonally recurring bloom phenomena. Their studies revealed that with a changing liberation rate, toxin can contribute to the explanation for algal bloom. The work of Blauw et al. [29] done in the Dutch coastal waters, used a fuzzy logic approach to relate foaming events, Phaeocystis globosa and environmental parameters such as irradiance, mixed layer and nutrient availability. Their result gave an insight of foam formation and provided a base for more detailed modelling efforts. Environmental variables such as temperature, salinity, light, nutrients, location, time of year and freshwater discharge were used to predict the occurrence of the toxigenic diatom Pseudonitzschia bloom using a logistic GLM approach. Their study identified several environmental variables associated with Pseudonitzschia blooms but could not pinpoint environmental indicators of the presence of its associated toxic agent [30]. Banerjee et al. [31] with a Monod-Haldane response approach analysed the phytoplankton-toxic phytoplankton-zooplankton interaction concluded that the zooplankton population can survive with the existence of toxic phytoplankton.

In this paper, GLM of toxigenic phytoplankton species-environmental variables interaction to analyse the potential influence of environmental variables on toxin production in the Nigerian coast. To do this, environmental variables and toxin-producing algae were integrated into the proposed model to ascertain the response of the toxigenic species to abiotic variables. This will assist us to understand and predict toxin production dynamics and the future occurrence.

The aim of this study is to investigate the applicability of mathematical modelling to predict the occurrence of toxin-producing phytoplankton in Nigerian coastal waters. It will apply data set over large temporal and spatial scales to support modelling and prediction of toxin-producing phytoplankton.

\section{Materials and Method}

\subsection{Study Area}

The sampling area consists of 53 stations in ten sampling locations across eight coastal states in south-south and south-west Nigeria which extends from Lagos State in south-west to Cross River State in south-south (Figure 1). The study was carried out in the Nigerian Coast-Atlantic Ocean and adjoining waterbodies, 


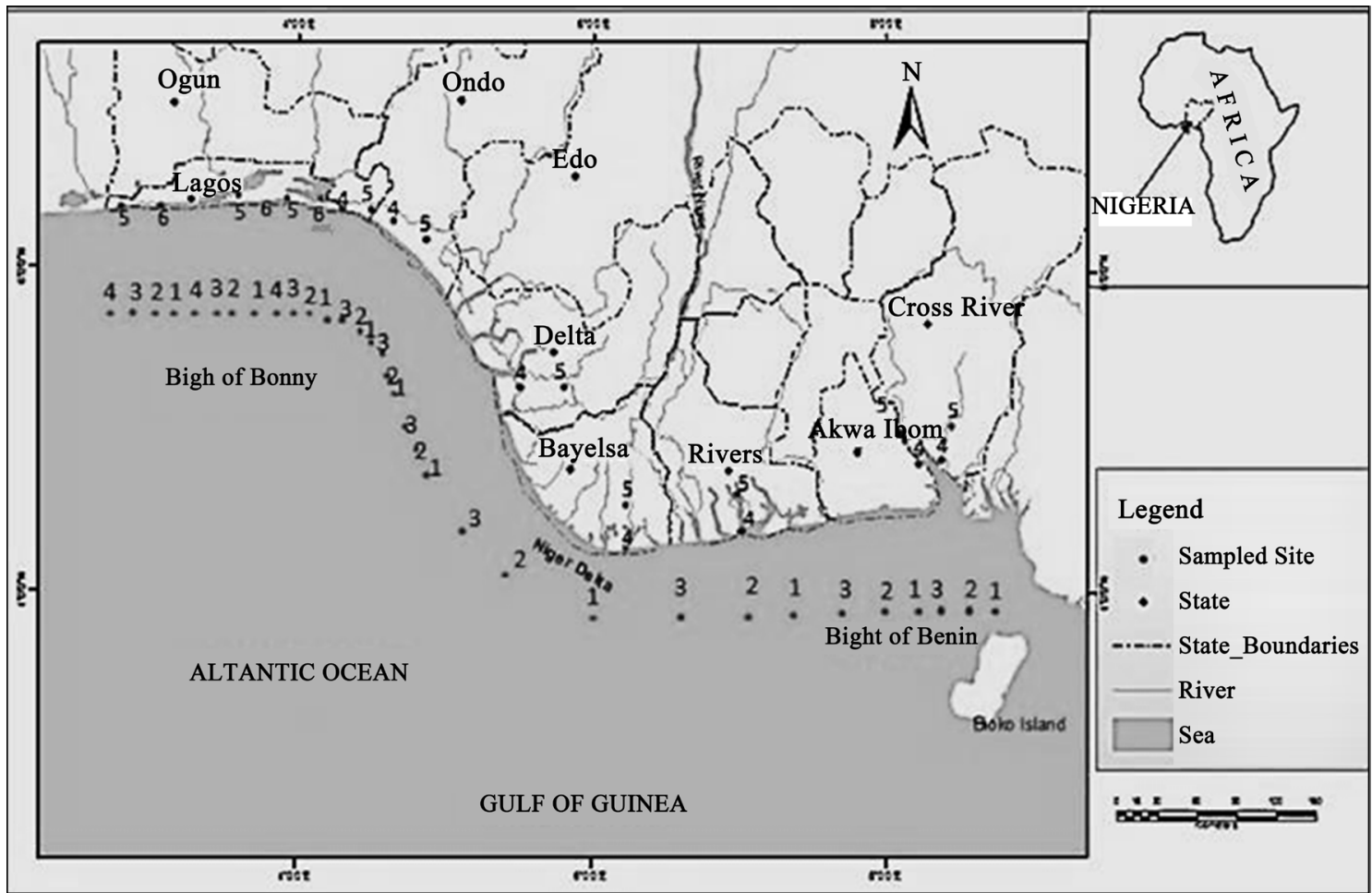

Figure 1. Map of study area: Coastal Waters of Nigeria, Gulf of Guinea, West Africa.

from the Bight of Bonny to Bight of Benin in the Gulf of Guinea. The sampling sites vary from freshwater to marine water.

\subsection{Sample Collection}

Separate seawater samples for in situ measures physico-chemical parameters and phytoplankton species abundance and toxin producing phytoplankton were collected using a transparent one liter container at a depth of 10 meters, using a Lund tube. Collection of samples were done in the 10 sampling sites within a year (2014-2015) in March, 2014 (dry-wet), July 2014 (wet), October 2014 (wet-dry) and January 2015 (dry) seasons.

\subsection{Phytoplankton Identification and Enumeration}

Phytoplankton identification was done through observation of their gross morphology and with the aid of appropriate texts [32] [33] [34] [35] [36] and enumeration was done using the Lackey method [37].

\subsection{Modelling Methodology}

A Generalized Linear Model (GLM) (empirical models) was formulated to predict the population size (abundance) of Cyanophyta $(A)$, Oscillatoria $(B)$, Dinophyta $(E)$, as well as the total phytoplankton abundance $(H)$ and toxic algae abundance $(I)$, for four different months in a year, namely March (Dry-wet period), July (Wet period), October (Wet-dry period) and January (dry period).

The models are given in (1) while the coefficients of the models, written as 
$\beta_{i}(i=1, \cdots, 12)$, for each of the 12 input variables are given in Tables $1-4$ (corresponding) to the four months of interest.

The model takes in 12 input variables, namely $\mathrm{pH}$, salinity, $\mathrm{PO}_{4}, \mathrm{NO}_{3}, \mathrm{Fe}$, Water temperature, $\mathrm{DO}$, turbidity, $\mathrm{Si}, \mathrm{SO}_{4}$ and location determined by the Latitude and Longitude coordinates. The models were fitted using data collected from 53 locations (Figure 1).

\section{Model}

\section{Generalized Linear Model (GLM)}

$$
\begin{aligned}
Y= & \beta_{0}+\beta_{1}[\mathrm{pH}]+\beta_{2}[\text { Salinity }]+\beta_{3}\left[\mathrm{PO}_{4}\right]+\beta_{4}\left[\mathrm{NO}_{3}\right]+\beta_{5}[\mathrm{Fe}] \\
& +\beta_{6}[\text { Water Temperature }]+\beta_{7}[\text { Dissolved Oxygen }] \\
& +\beta_{8}[\text { Turbidity }]+\beta_{9}[\mathrm{Si}]+\beta_{10}\left[\mathrm{SO}_{4}\right]+\beta_{11}[\text { Lat. }]+\beta_{12}[\text { Long. }]
\end{aligned}
$$

$Y=$ population of species. $(Y)$ can take any of the following:

$A=$ Cyanophyta.

$B=$ Oscillatoria.

$E=$ Dinophyta.

$H=$ Total phytoplankton abundance.

$I=$ Total Toxic species abundance.

The interactive effects of silicate and iron was also modeled to elicit effect of these nutrients on the density and occurrence of toxic algae/phytoplankton and total phytoplankton abundance.

\section{March}

Table 1. Coefficients of the model (1) predicting the population of the species specified here in for the month of March.

\begin{tabular}{cccc}
\hline & $E$ & $H$ & $I$ \\
\hline$\beta_{0}$ & 3.0876 & 9.5625 & 2.4779 \\
$\beta_{1}$ & 0.2162 & 0.3572 & 0.0695 \\
$\beta_{2}$ & 0.0296 & -0.0731 & -0.0461 \\
$\beta_{3}$ & -5.6102 & -0.3415 & -0.8939 \\
$\beta_{4}$ & 1.0443 & 0.3203 & 0.5680 \\
$\beta_{5}$ & -0.0626 & -0.0408 & 0.2020 \\
$\beta_{6}$ & 0.0856 & 0.0204 & 0.0969 \\
$\beta_{7}$ & -0.1018 & 0.2988 & 0.2897 \\
$\beta_{8}$ & -0.0212 & 0.0010 & -0.0135 \\
$\beta_{9}$ & -0.0006 & -0.0001 & -0.0012 \\
$\beta_{10}$ & 0.0007 & 0.0001 & 0.0005 \\
$\beta_{11}$ & 0.6020 & 0.0225 & 0.5255 \\
$\beta_{12}$ & -0.0180 & -0.0816 & -0.0993 \\
\hline & & &
\end{tabular}




\section{July}

Table 2. Coefficients of the model (1) predicting the population of the species specified here in for the month of July.

\begin{tabular}{cccccc}
\hline & $A$ & $B$ & $E$ & $H$ & $I$ \\
\hline$\beta_{0}$ & 11.7201 & 18.4822 & 7.6484 & 10.4401 & 0.7353 \\
$\beta_{1}$ & -0.0244 & -0.7740 & -0.5949 & -3.9291 & -0.7454 \\
$\beta_{2}$ & -0.1031 & -0.1006 & -0.0221 & -0.0757 & -0.1217 \\
$\beta_{3}$ & 3.3943 & 3.9021 & -1.8595 & -15.2965 & -27.4475 \\
$\beta_{4}$ & -2.1913 & -2.5930 & 1.2509 & 1.4387 & 1.3954 \\
$\beta_{5}$ & -0.7799 & -0.4307 & -0.2063 & -0.3444 & 0.0395 \\
$\beta_{6}$ & -0.1201 & -0.1387 & -0.0246 & 0.6474 & -0.0847 \\
$\beta_{7}$ & 0.0070 & 0.3958 & 0.1645 & 0.3474 & 0.9817 \\
$\beta_{8}$ & -0.0110 & -0.0478 & -0.0410 & 0.1122 & -0.0423 \\
$\beta_{9}$ & -0.0006 & -0.0039 & 0.0010 & 0.0037 & -0.0039 \\
$\beta_{10}$ & 0.0005 & 0.0003 & 0.0024 & 0.0019 & 0.0007 \\
$\beta_{11}$ & 0.8133 & 0.4896 & 0.5430 & 2.8631 & 1.8135 \\
$\beta_{12}$ & -0.1361 & -0.3448 & 0.4664 & -2.0538 & 0.8333 \\
\hline
\end{tabular}

\section{October}

Table 3. Coefficients of the model (1) predicting the population of the species specified here in for the month of October.

\begin{tabular}{cccccc}
\hline & $A$ & $B$ & $E$ & $H$ & $I$ \\
\hline$\beta_{0}$ & 10.0971 & 17.3518 & 26.8601 & 4.4715 & 13.4596 \\
$\beta_{1}$ & 0.6949 & 1.5798 & -1.7140 & 0.0140 & 0.0811 \\
$\beta_{2}$ & 0.0665 & 0.3802 & 0.0625 & 0.0229 & -0.0259 \\
$\beta_{3}$ & -0.2503 & -0.1035 & -0.2092 & 0.3925 & -0.7602 \\
$\beta_{4}$ & -5.7295 & -100.6299 & 0.2874 & 2.3153 & -1.7240 \\
$\beta_{5}$ & 0.8857 & 0.0157 & 0.2016 & -0.0847 & -0.0597 \\
$\beta_{6}$ & 0.0087 & -0.4866 & -0.1657 & 0.1544 & 0.0122 \\
$\beta_{7}$ & -0.1877 & -1.5629 & 0.4446 & 0.1316 & 0.1301 \\
$\beta_{8}$ & -0.0020 & -0.0903 & 0.0550 & 0.0243 & 0.0140 \\
$\beta_{9}$ & -0.0091 & -0.0258 & 0.0030 & -0.006 & -0.0063 \\
$\beta_{10}$ & -0.0015 & -0.0073 & 0.0002 & -0.000001 & -0.0003 \\
$\beta_{11}$ & -0.5676 & 1.5172 & -0.2134 & 0.4309 & -0.2259 \\
$\beta_{12}$ & -0.2308 & 0.0667 & -0.5688 & 0.0325 & -0.4870 \\
\hline
\end{tabular}




\section{January}

Table 4. Coefficients of the model (1) predicting the population of the species specified here in for the month of January.

\begin{tabular}{cccccc}
\hline & $A$ & $B$ & $E$ & $H$ & $I$ \\
\hline$\beta_{0}$ & -156.9272 & -27.3615 & -36.5933 & -6.6046 & -38.2888 \\
$\beta_{1}$ & 3.0826 & 2.0200 & 2.3151 & 0.0120 & 2.4116 \\
$\beta_{2}$ & -0.8456 & -0.2451 & -0.0872 & -0.0772 & -0.1482 \\
$\beta_{3}$ & -13.5519 & -14.9825 & -2.6929 & 5.2067 & -2.9423 \\
$\beta_{4}$ & -2.8867 & 8.5869 & 7.9305 & -3.2953 & 7.4332 \\
$\beta_{5}$ & 6.9070 & 0.0006 & 1.2980 & 0.3274 & 1.1012 \\
$\beta_{6}$ & 2.6715 & 0.9348 & 0.8447 & 0.2877 & 0.9843 \\
$\beta_{7}$ & 3.6272 & -0.4475 & -1.1685 & 0.5134 & -1.1316 \\
$\beta_{8}$ & -0.2608 & -0.0081 & -0.1056 & -0.0351 & -0.0602 \\
$\beta_{9}$ & 0.0490 & -0.0270 & 0.0390 & -0.0014 & 0.0214 \\
$\beta_{10}$ & 0.0077 & 0.0022 & 0.0013 & 0.0003 & 0.0019 \\
$\beta_{11}$ & 5.9619 & 0.4513 & 2.6559 & 1.4506 & 2.1693 \\
$\beta_{12}$ & -0.3693 & -0.9115 & -0.6016 & 0.0537 & -0.6675 \\
\hline
\end{tabular}

\section{Results}

These plots (obtained using models (1)) show that the location of the phytoplankton is significant in determining their abundance during the months of interest. The variations in the total phytoplankton abundance and the toxic form abundance seem to be significantly affected by location at different times of the year.

The models from (1) gives a very good fit for the data collected and can be used to predict the populations specified herein with variations in the input parameters during the specific period of interest.

Figure 2(a), Figure 2(b), Figure 3(a) and Figure 3(b) illustrate the surface and stem plots of toxigenic species and total phytoplankton abundance of the Nigerian coast for dry-wet season. The surface and stem plots for total phytoplankton abundance and toxic algae abundance were similar in this season. This is an indication that the phytoplankton abundance and toxic algae abundance were equally distributed in terms of density in each sampling site. Specifically, Ondo and Ogun in the south-west had significantly high total phytoplankton and toxic algae abundance in this season.

Figure 4(a), Figure 4(b), Figure 5(a) and Figure 5(b) show the surface and stem plots of toxigenic species and total phytoplankton abundance of the Nigerian coast for wet season. The surface and stem plots for total for total phytoplankton abundance and toxic algae abundance were noticeably dissimilar, pointing to the fact that the total phytoplankton abundance and toxic algae abundance did not correlated in terms of their densities in each location. Locations 

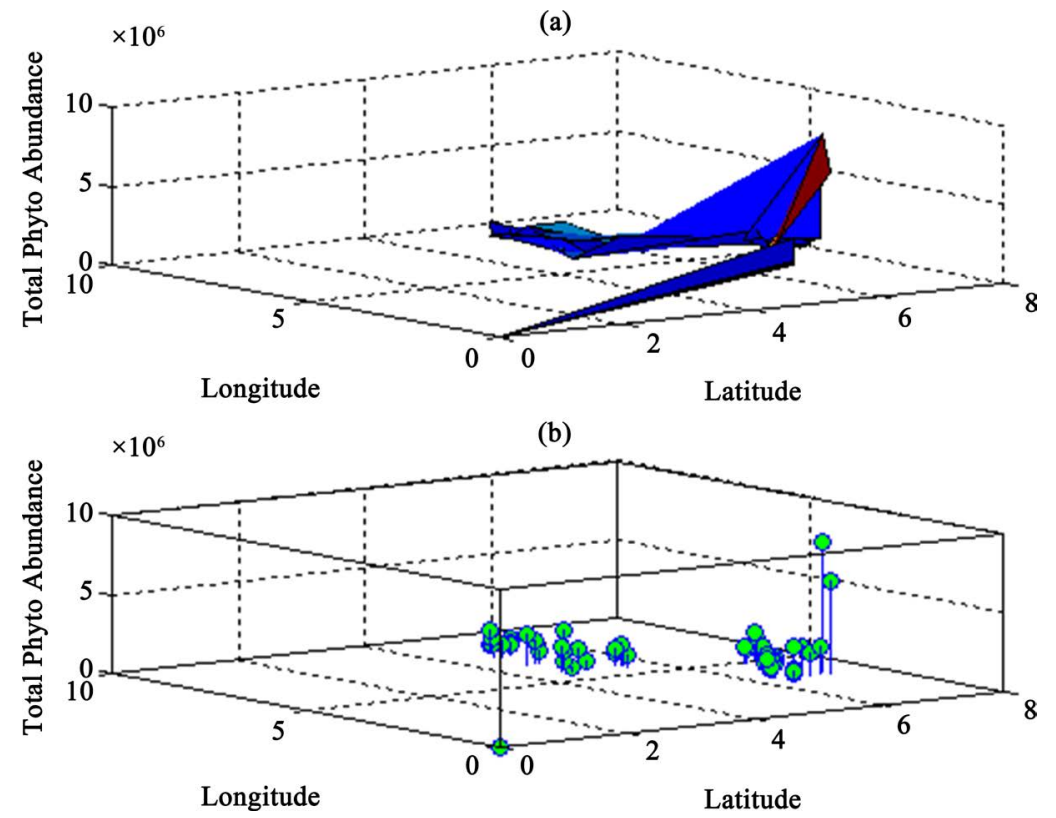

Figure 2. Total phytoplankton abundance for dry-wet season (a) Surface plot; (b) Stem plot.
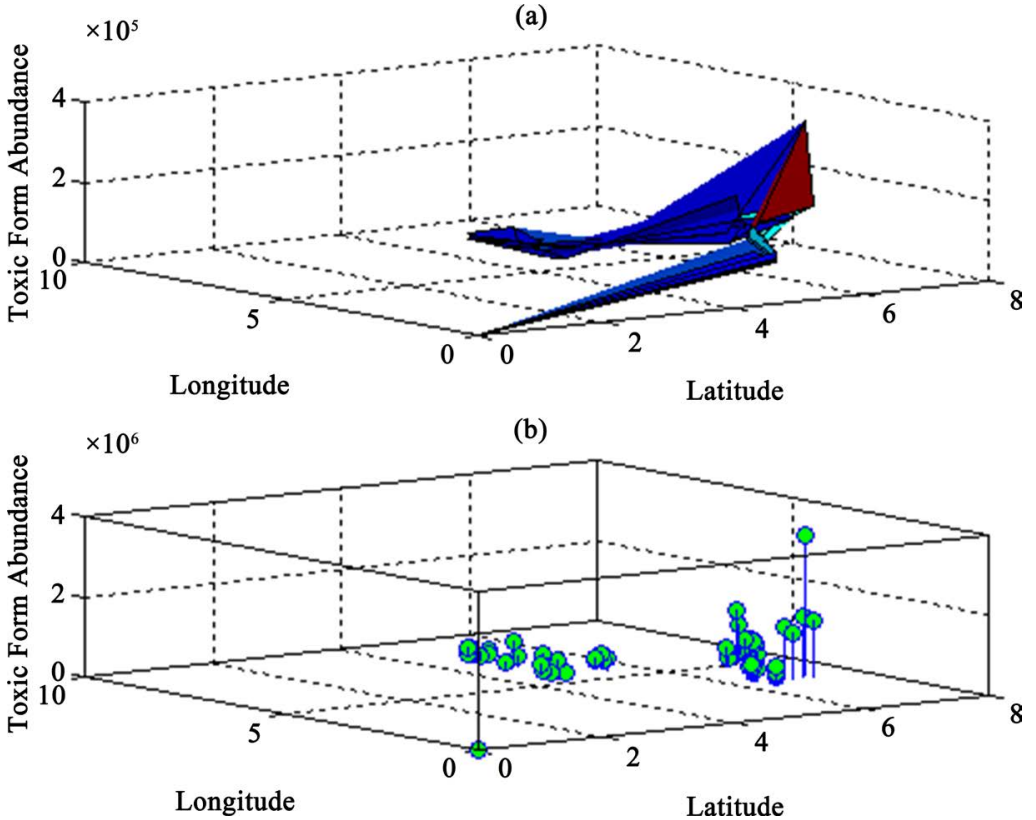

Figure 3. Toxic algae abundance for dry-wet season (a) Surface plot; (b) Stem plot.

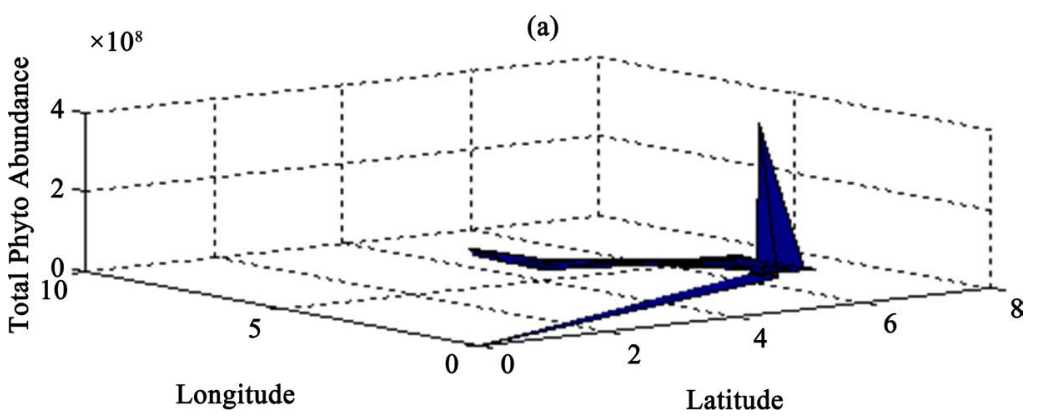




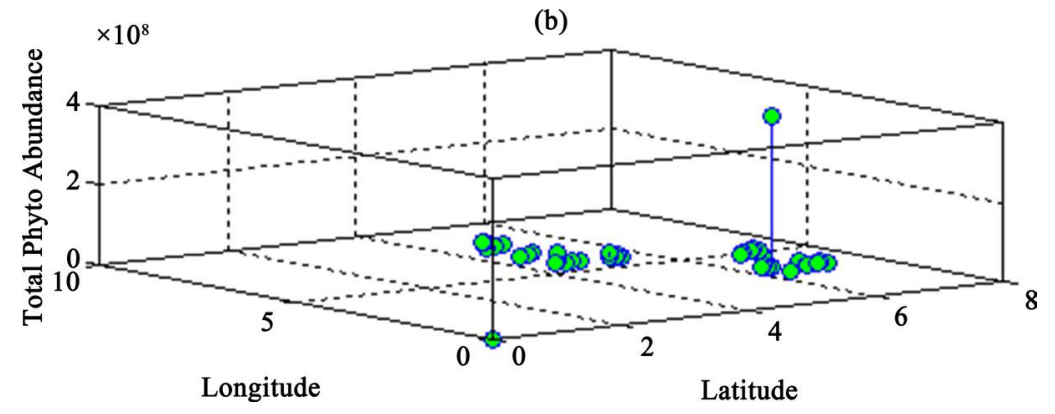

Figure 4. Total phytoplankton abundance for wet season (a) Surface plot; (b) Stem plot.
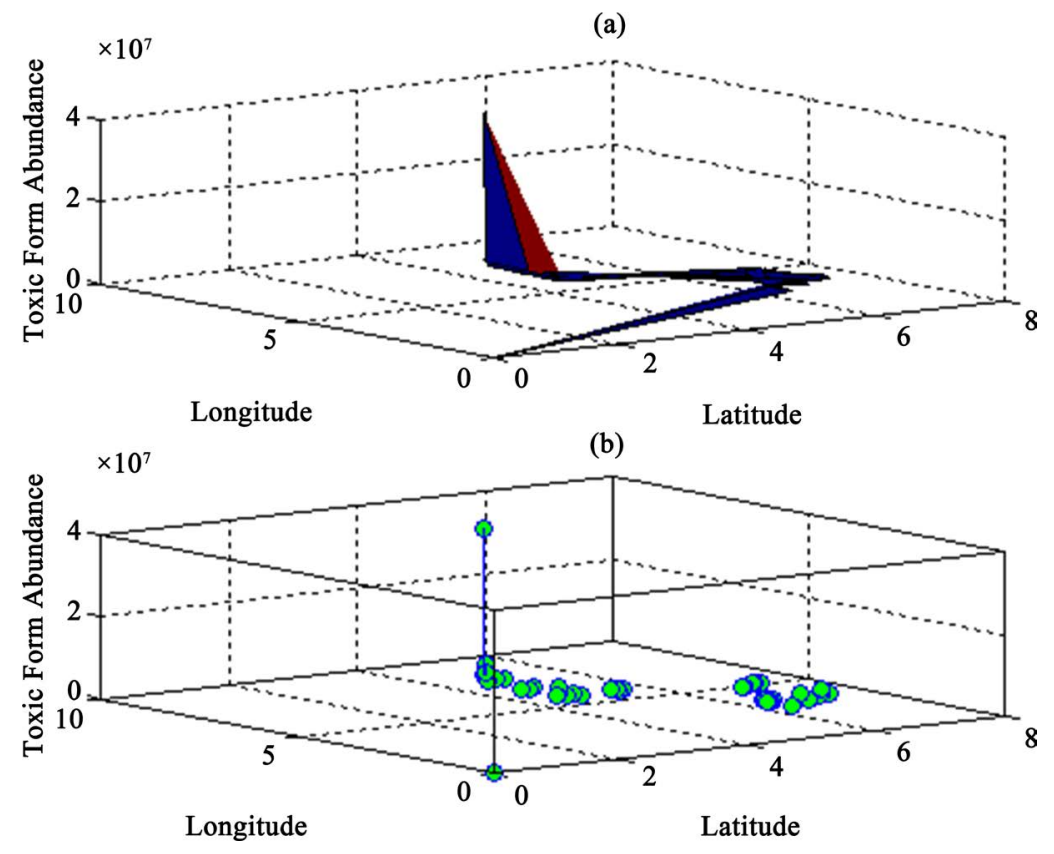

Figure 5. Toxic algae abundance for wet season (a) Surface plot; (b) Stem plot.

with abundant phytoplankton had few toxic algae while sites with fewer phytoplankton had abundant toxic algae. Precisely, the Lagos axis of the Atlantic Ocean had significantly high total phytoplankton abundance in this season. On the other hand, the toxic algae were abundant in the south-south locations of Cross River and Akwa Ibom.

Figure 6(a), Figure 6(b), Figure 7(a) and Figure 7(b) shows the surface and stem plots of toxigenic species and total phytoplankton abundance of the Nigerian coast for wet-dry season. The surface plot and stem plot for the total phytoplankton abundance in this season indicated that phytoplankton abundance was evenly distributed across all the sampling sites from south-south to south-west. However, the stem plot and surface plot for toxic algae indicated that there was significant abundance of toxic algae in the south-west locations.

Figure 8(a), Figure 8(b), Figure 9 (a) and Figure 9(b) shows the surface and stem plots of toxigenic species and total phytoplankton abundance of the Nigerian coast for dry season. The surface plot and stem plots of the total phytoplankton abundance and toxic algae abundance were not similar. The plots for the 

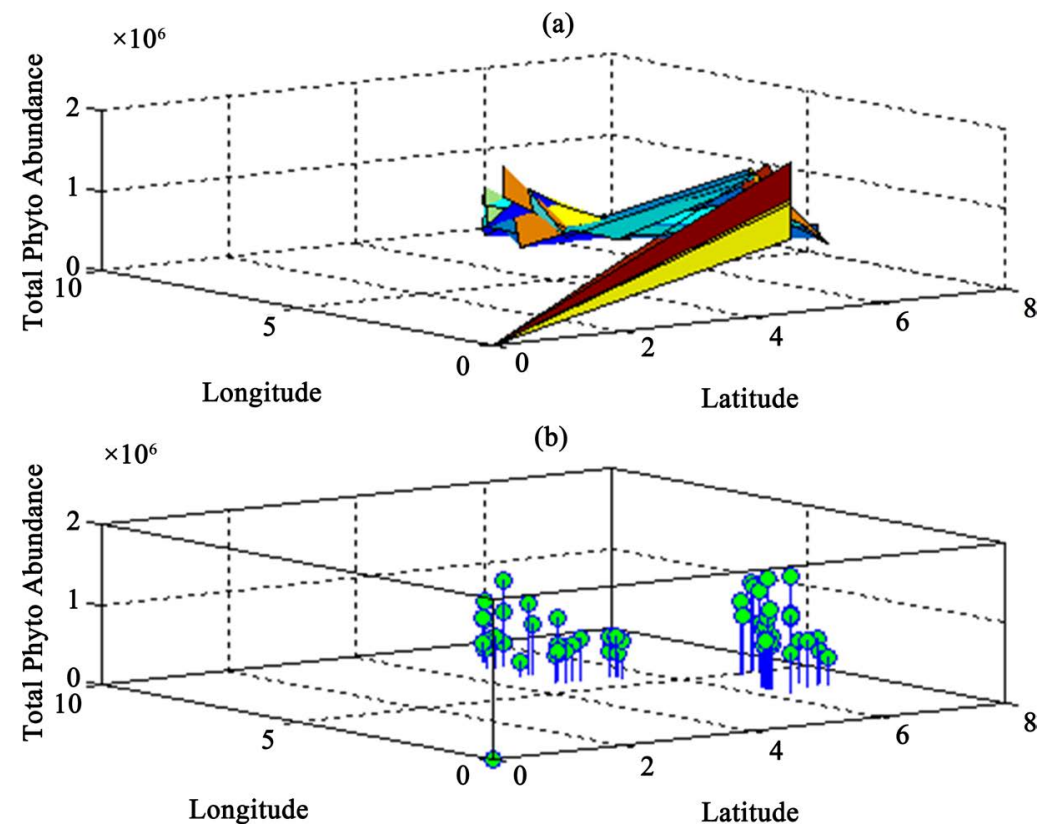

Figure 6. Total phytoplankton abundance for wet-dry season (a) Surface plot; (b) Stem plot.
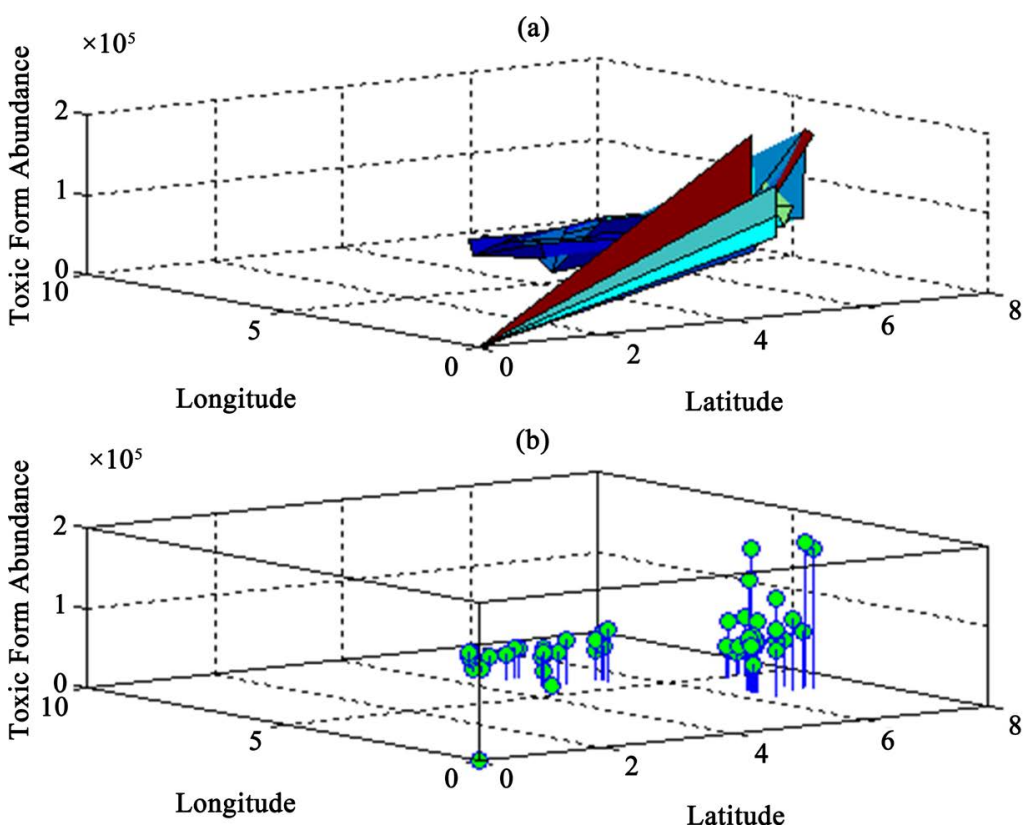

Figure 7. Toxic algae abundance for wet-dry season (a) Surface plot; (b) Stem plot.

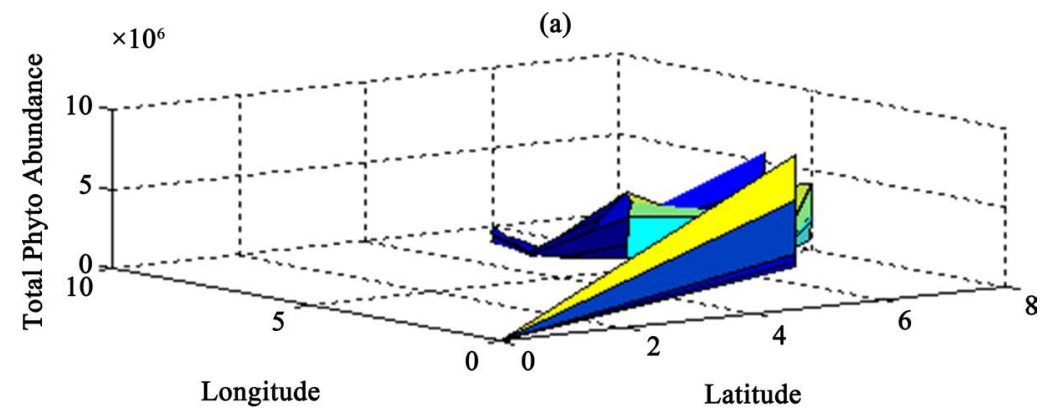




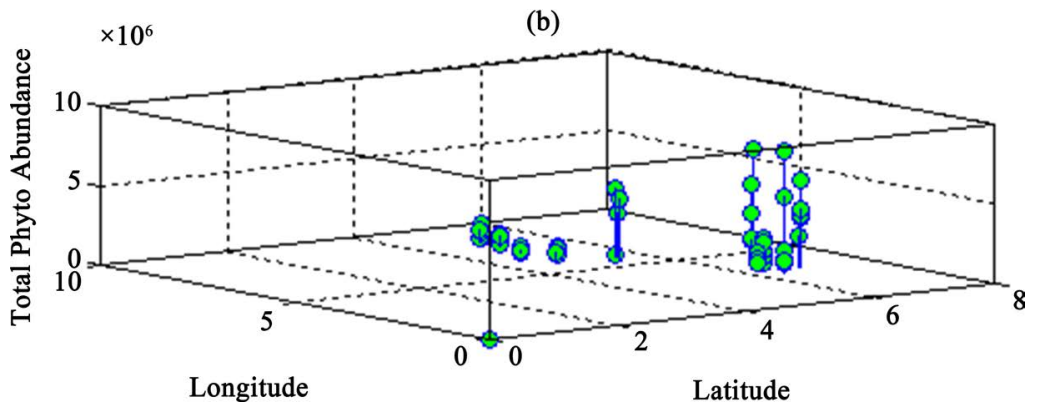

Figure 8. Total phytoplankton abundance for dry season (a) Surface plot; (b) Stem plot.
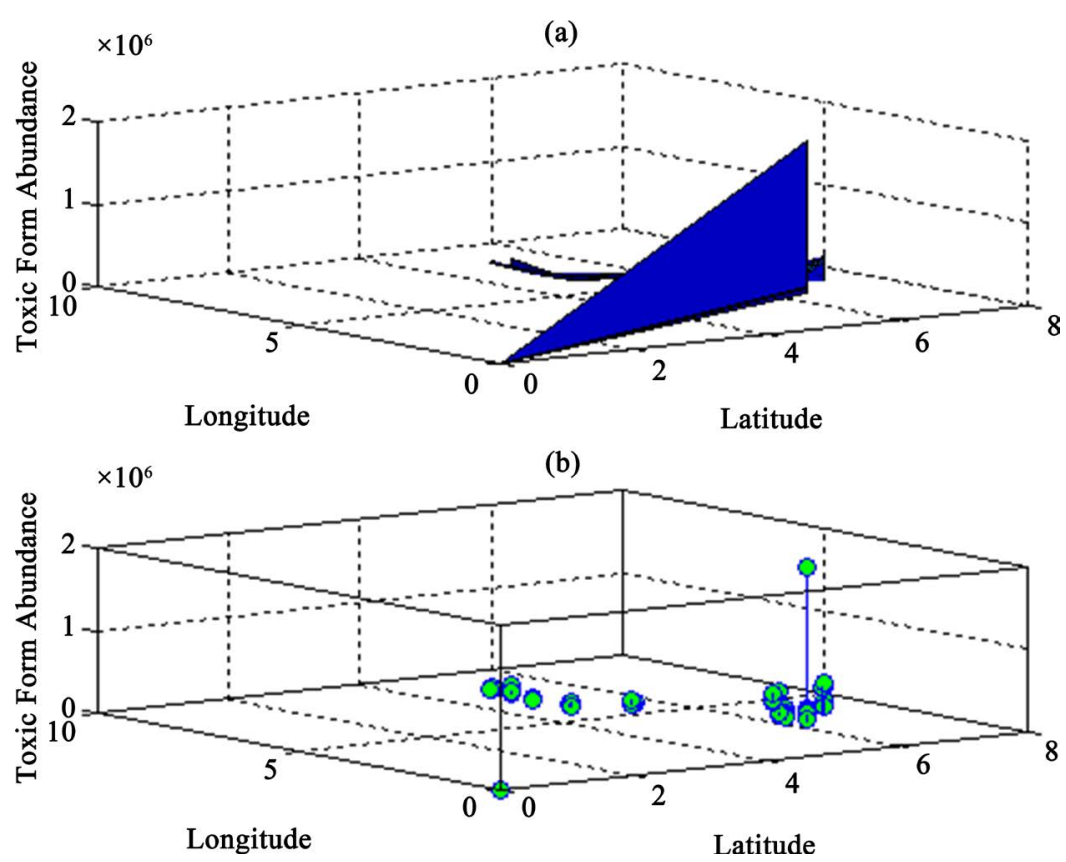

Figure 9. Toxic algae abundance for dry-season (a) Surface plot; (b) Stem plot.

total phytoplankton abundance indicated that the south-west locations had significantly high phytoplankton abundance when compared to the south-south locations. Furthermore, the plots for the toxic algae abundance showed that Ondo and Ogun axes of the Atlantic Ocean had significantly high abundance of the toxic algae.

All plots were obtained using the model (1), with the appropriate coefficients in Tables 1-4.

Figure 10(a) and Figure 10(b) depict the stem plots of the effect of silicon $(\mathrm{Si})$ and iron $(\mathrm{Fe})$ on the total phytoplankton abundance and toxic for abundance across the sampling sites respectively in the dry-wet season. The plots indicated that Si had no effect while Fe had effect on the distribution of the population total phytoplankton and toxic form abundance. Figure 10 shows clearly that iron concentration seems to be more significant in both abundances compared to the impact of Si on both populations, in the dry-wet period.

The distribution cut across different concentrations of iron. With respect to Figure 10(a), two isolated spots had increased total phytoplankton abundance 
while the Figure 10(b) shows relative increase in the toxic form abundance in some sampling locations.

Figure 11(a) and Figure 11(b) depict the stem plots of the effect of $\mathrm{Si}$ and $\mathrm{Fe}$ on the total phytoplankton abundance and toxic for abundance across the sampling sites respectively in the wet period. The plot indicated that iron at various concentrations had significant impact on occurrence and distribution of toxic

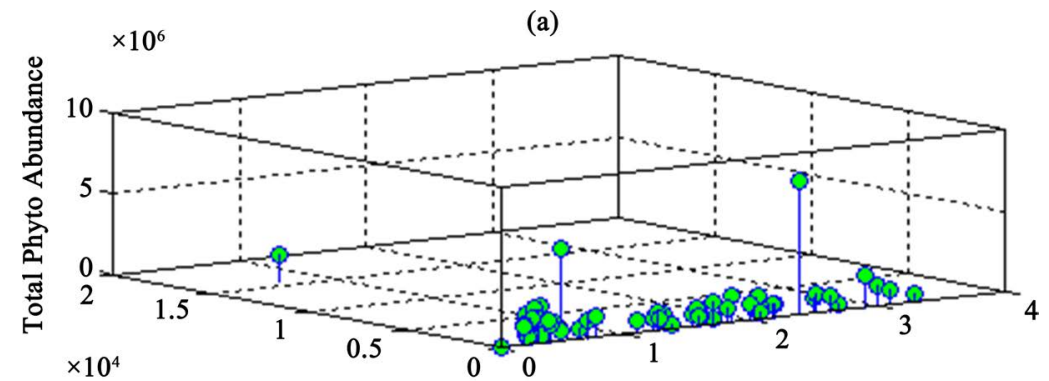

$\mathrm{Si}$

(b)

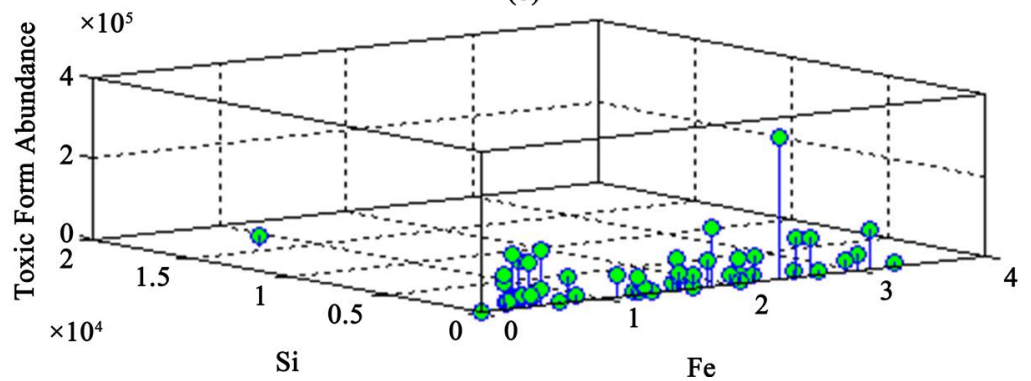

Figure 10. Stem plots of the (a) total phytoplankton abundance (b) toxic form abundance as a function of $\mathrm{Fe}$ and $\mathrm{Si}$, for the dry-wet period. Values of $\mathrm{Si}$ and $\mathrm{Fe}$ are expressed in $\mathrm{mg} / \mathrm{L}$.

(a)

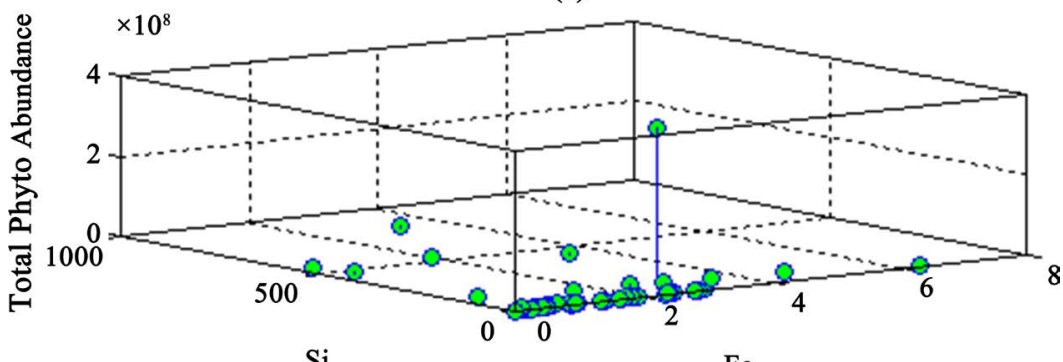

(b)

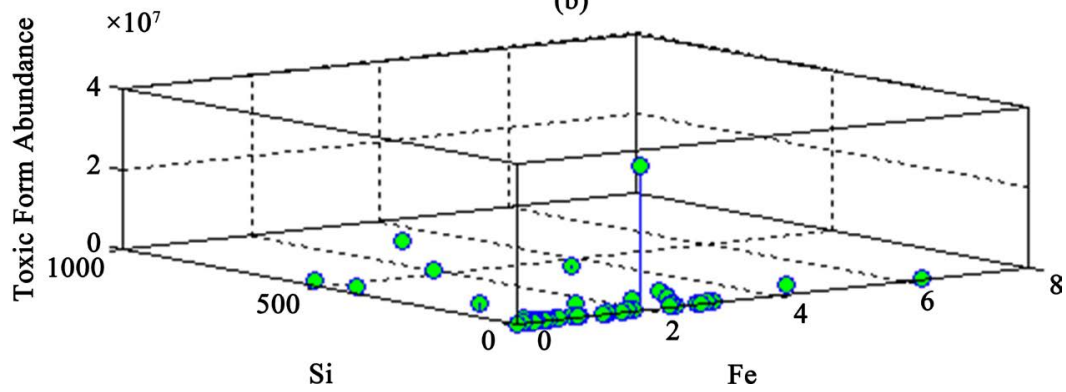

Figure 11. Stem plots of the (a) total phytoplankton abundance (b) toxic form abundance as a function of $\mathrm{Fe}$ and $\mathrm{Si}$, for the wet period. 
form and the total phytoplankton abundance while silicon had relative effect on the distribution of both populations. In the wet period, it seems that $\mathrm{Fe}$ was more significant in concentration compared to Si in determining the total phytoplankton abundance and toxic form abundance (with the Si playing a significant role in a few instances as seen in Figure 11). This trend was also observed in Figure 12, that Fe seems more significant than $\mathrm{Si}$ in determining the total phytoplankton abundance and toxic form abundance in the month of wet-dry period. However, total phytoplankton and toxic form abundance increased only at one spot.

Figure 12(a) and Figure 12(b) represent the stem plots of the effect of Si and $\mathrm{Fe}$ on the total phytoplankton abundance and toxic for abundance across the sampling sites respectively in the wet-dry period. Iron had a significant influence on the distribution of the population of both groups but silicon had relatively no effect. The distribution cut across different concentrations of iron. Also, there were relative increase in the total phytoplankton and toxic form abundance in some sites as indicated in the stem plot.

Figure 13(a) and Figure 13(b) depict the stem plots of the effect of Si and Fe on the total phytoplankton abundance and toxic for abundance across the sampling sites respectively in the dry period. During this period, it is also observed that Fe was more significant in determining the total phytoplankton abundance and toxic form abundance compared to the impact of $\mathrm{Si}$ on these populations.

Iron had a significant impact on the distribution of the population of both groups but silicon had effect mainly on two sampling sites. At lower concentration, iron had relative increase in the total phytoplankton abundance but there was no effect on the toxic form abundance at all concentrations. However, silicon had significant increase on the total phytoplankton and toxic form abundance

(a)

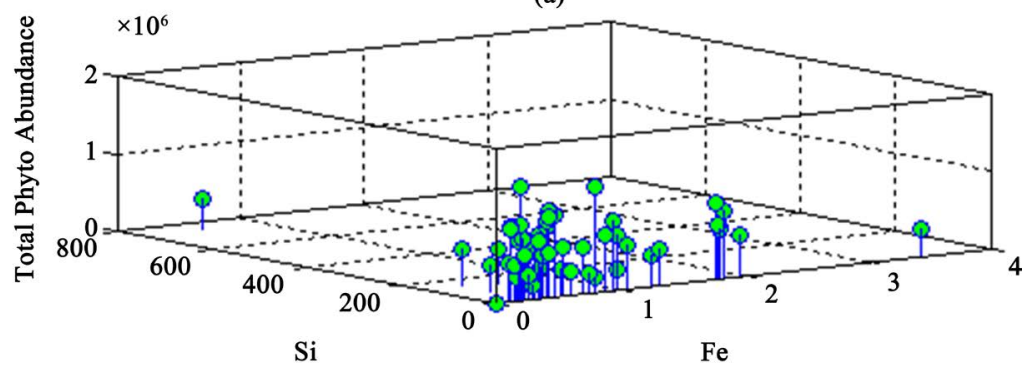

(b)

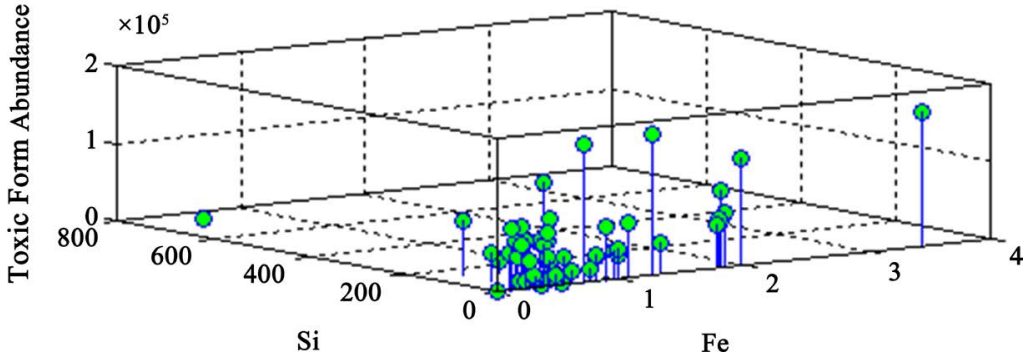

Figure 12. Stem plots of the (a) total phytoplankton abundance (b) toxic form abundance as a function of $\mathrm{Fe}$ and $\mathrm{Si}$, for the wet-dry period. 


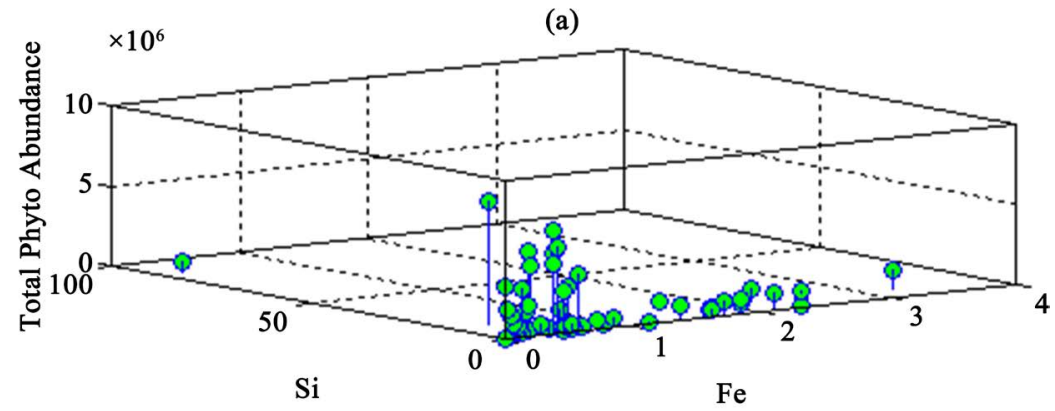

(b)

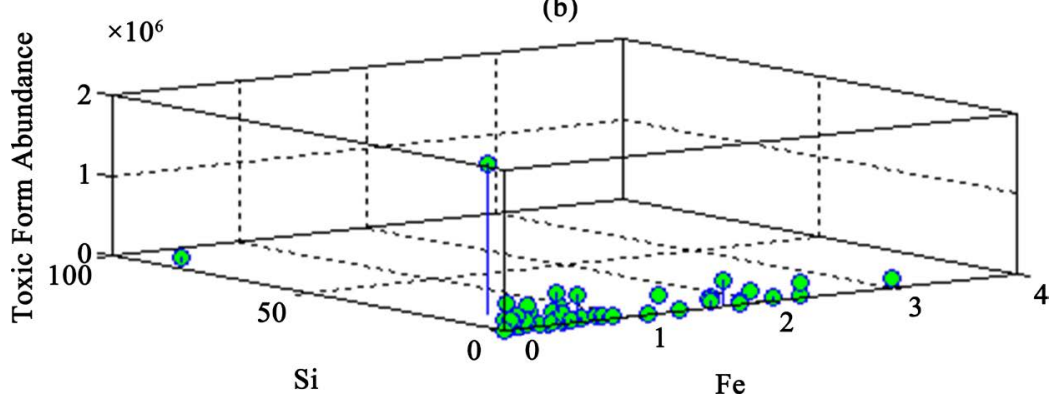

Figure 13. Stem plots of the (a) total phytoplankton abundance (b) toxic form abundance as a function of $\mathrm{Fe}$ and $\mathrm{Si}$, for the dry period.

only at one sampling site.

Overall Si had more effect and made higher contribution in promoting both phytoplankton abundance and toxic form abundance in wet period, corresponding to the season of its highest concentration.

\section{Discussion}

The modelling for this study implicated the effects of environmental variables on the total toxin-producing phytoplankton and total phytoplankton abundance. While the abundance of the total phytoplankton community could be linked to nutrient enrichment or sufficiency, toxigenic species abundance may be a resultant effect of certain nutrient limitation or changes in some environmental variables. HABs, inclusive of toxin-producing forms, have been indicated to occur in areas with strong regional upwelling of nutrients [38] which provides inorganic nutrients and subsurface phytoplankton to the surface, culminating in phytoplankton blooms. The effects of potential influence of cultural eutrophication on harmful algae have been amply pointed out by several researchers [4] [9] [10] [11] [12] [39].

It has been proved that anthropogenic input promotes the development and persistence of harmful algal blooms at many locations in the world [12]. The growth, toxicity, and geographic distribution of harmful algae have increased with environmental factors such as nutrient enrichment and warmer water temperatures [40] [41].

Coastal eutrophication or nutrient enrichment is invoked by high inorganic nutrients from river discharges [42] and this culminate in HABs [43] [44] [45]. Nutrient enrichment in coastal areas arises from high-inorganic nutrients in freshwa- 
ter runoff, sewage discharge, agricultural fertilizers, and nearby high-density coastal aquaculture [46].

Reports of Graneli and Flynn [47] stressed that both macronutrients and micronutrients have profound influence on harmful effects expression via control of cellular toxin content. Such influences occur in response to absolute nutrient concentration, nutrient ratios, as well as nutrient speciation.

Changes in Redflield ratio leads to shifts in phytoplankton composition, providing insights into the dynamics of nutrient regulation of phytoplankton assemblages [8]. Some phytoplankton species including harmful algae are able to thrive in non-Redfieldian proportions because of accessibility to variable forms of nutrients. Many HAB species, including toxic representatives, have the ability to acquire nutrients when in disproportionate supply, and also can produce toxic compounds, making these species excellent competitors under non-Redfieldian conditions.

The numerical result of the modelling revealed that there was seasonal variations of toxigenic species and total phytoplankton in the two distinct regions of south-west and south-south of the Nigerian coast. South-west had high toxigenic species and phytoplankton abundance in all the seasons except for the wet season where it had low abundance of toxin-producing phytoplankton. With regards to the south-south region, there was low phytoplankton abundance in all the seasons apart from the wet season. South-south region also had low abundance of toxin producing phytoplankton in all the season with exception of the dry-wet season. Researchers have established that toxin production may not be associated entirely with phytoplankton abundance, and also, the ability of a species to produce toxins does not directly translate to its bloom production [48]. Nevertheless, even at these low abundances, their presence indicates that under the right environmental and physiological conditions, toxin production may be triggered, which can lead to devastating effects in the coastal waters of Nigeria.

Silica influences diatoms in particular. The isolated response/high abundance in the wet and dry periods could be ascribable to the toxic diatom species, particularly, Pseudonitzschia species.

The influence of iron on the biomass and density of phytoplankton in oceanic waters has been corroborated by Takeda [49].

\section{Conclusion}

This work represents a pioneering effort at modelling toxic algal species in Nigeria marine and/or coastal ecosystem. The model provided a very good fit for the data collected and can be used to predict the harmful algal populations with variations in the input environmental variables. It has revealed that geographic locations and time of the year play a significant role in the abundance of toxic algae. The result obtained will provide resource managers with the requisite information and tools in developing effective strategies for the mitigation and management of harmful algal blooms and their concomitant frequently devas- 
tating impacts on coastal environments.

\section{Acknowledgements}

The authors are grateful to the Tertiary Education Trust Fund National Research grant (TETF/NRF 2009). Also appreciated are Jeffrey Ogbebor, Osasere Omoruyi, Denise Mukoro and Solomon Isagba for their assistance in the collection of samples.

\section{Conflicts of Interest}

The authors declare no conflicts of interest regarding the publication of this paper.

\section{References}

[1] Hallegraeff, G.M. (1993) A Review of Harmful Algal Blooms and Their Apparent Global Increase. Phycologia, 32, 79-99.

https://doi.org/10.2216/i0031-8884-32-2-79.1

[2] Tillmann, U., Alpermann, T., John, U. and Cembella, A. (2008) Allelochemical Interactions and Short-Term Effects of the Dinoflagellate Alexandrium on Selected Photoautotrophic and Heterotrophic Protists. Harmful Algae, 7, 52-64. https://doi.org/10.1016/j.hal.2007.05.009

[3] Zaccaroni, A. and Scaravelli, D. (2008) Toxicity of Sea Algal Toxins to Humans and Animals. In: Evangelista, V., et al., Eds., Algal Toxins: Nature, Occurrence, Effect and Detection, Springer Science + Business Media B.V., Berlin, 91-157. https://doi.org/10.1007/978-1-4020-8480-5_4

[4] Anderson, D.M., Glibert, P.M. and Burkholder, J.M. (2002) Harmful Algal Blooms and Eutrophication: Nutrient Sources, Composition, and Consequences. Estuaries, 25, 704-726. https://doi.org/10.1007/BF02804901

[5] Paerl, H.W. and Huisman, J. (2008) Blooms Like It Hot. Science, 320, 57-58. https://doi.org/10.1126/science.1155398

[6] Davidson, K., Gowen, R.J, Harrison, P.J., Fleming, LE, Hoagland, P. and Moschonas, G. (2014) Anthropogenic Nutrients and Harmful Algae in Coastal Waters. Journal of Environmental Management, 146, 206-216. https://doi.org/10.1016/j.jenvman.2014.07.002

[7] Anderson, D.M. (2009) Approaches to Monitoring, Control and Management of Harmful Algal Blooms (HABs). Ocean \& Coastal Management, 52, 342-347. https://doi.org/10.1016/j.ocecoaman.2009.04.006

[8] Glibert, P.M. and Burkholder, J.M. (2011) Harmful Algal Blooms and Eutrophication: "Strategies" for Nutrient Uptake and Growth outside the Redfield Comfort Zone. Chinese Journal of Oceanology and Limnology, 29, 724-738. https://doi.org/10.1007/s00343-011-0502-z

[9] Carmichael, W.W. (1997) The Cyanotoxins. Advances in Botanical Research, 27, 211-256. https://doi.org/10.1016/S0065-2296(08)60282-7

[10] Van Dolah, F.M. (2000) Marine Algal Toxins: Origins, Health Effects, and Their Increased Occurrence. Environmental Health Perspectives, 108, 133-141. https://doi.org/10.1289/ehp.00108s1133

[11] Glibert, P.M., Anderson, D., Gentien, P., Graneli, E. and Sellner, K. (2005) The Global, Complex Phenomena of Harmful Algal Blooms. Oceanography, 18, 136-147. 
https://doi.org/10.5670/oceanog.2005.49

[12] Heisler, J., Glibert, P.M., Burkholder, J.M., Anderson, D.M., Cochlan, W., Dennison, W.C., Dortch, Q., Gobler, C.J., Heil, C.A., Humphries, E., Lewitus, A., Magnien, R., Marshall, H.G., Sellner, K., Stockwell, D.A., Stoecker, D.K. and Suddleson, M. (2008) Eutrophication and Harmful Algal Blooms: A Scientific Consensus. Harmful Algae, 8, 3-13. https://doi.org/10.1016/j.hal.2008.08.006

[13] Omole, D.O. and Isiorho, S. (2011) Waste Management and Water Quality Issues in Coastal States of Nigeria: The Ogun State Experience. Journal of Sustainable Development in Africa, 13, 207-217.

[14] Ferreira, J.G., Andersen, J.H., Borja, A., Bricker, S.B., Camp, J., Cardoso da Silva, M., Garcés, E., Heiskanen, A.S., Humborg, C., Ignatiades, L., Lancelot, C., Menesguen, A., Tett, P., Hoepffner, N. and Claussen, U. (2011) Overview of Eutrophication Indicators to Assess the Environmental Status within the European Marine Strategy Framework Directive. Estuarine and Coastal Shelf Science, 93, 117-131. https://doi.org/10.1016/j.ecss.2011.03.014

[15] Kadiri, M.O. (2001) Some Marine Phytoplankton Species from Atlantic Ocean, Nigeria. Bioscience Research Communication, 13, 197-207.

[16] Landsberg, J.H. (2002) The Effects of Harmful Algal Blooms on Aquatic Organisms. Reviews in Fisheries Science, 10, 113-390. https://doi.org/10.1080/20026491051695

[17] Hitzfeld, B.C., Hoger, S.J. and Dietrich, D.R. (2000) Cyanobacterial Toxins: Removal during Water Treatment, and Human Risk Assessment. Environmental Health Perspectives, 108, 113-122. https://doi.org/10.1289/ehp.00108s1113

[18] Chorus, I. (2001) Cyanotoxins: Occurrence, Causes, Consequences. Springer, Berlin. https://doi.org/10.1007/978-3-642-59514-1

[19] Van Dolah, F.M., Roelke, D. and Greene, R.M. (2001) Health and Ecological Impacts of Harmful Algal Blooms: Risk Assessment Needs. Human Ecological Risk Assessment, 7, 1329-1345. https://doi.org/10.1080/20018091095032

[20] Anderson, C.R., Siegel, D.A., Kudela, R.M. and Brzezinski, M.A. (2009) Empirical Models of Toxigenic Pseuo-nitzschia Blooms: Potential Use as a Remote Detection Tool in the Santa Barbara Channel. Harmful Algae, 8, 478-492. https://doi.org/10.1016/j.hal.2008.10.005

[21] Ajuzie, C. and Houvenaghel, G. (2009) Preliminary Survey of Potentially Harmful Dinoflagellates in Nigeria's Coastal Waters. Fottea, 9, 107-120. https://doi.org/10.5507/fot.2009.010

[22] Kadiri, M.O. (2006) Phytoplankton Flora and Physico-Chemical Attributes of Some Waters in the Eastern Niger Delta Area of Nigeria. Nigerian Journal Botany, 19, 188-200.

[23] Kadiri, M.O. (2011) Notes on Harmful Algae from Nigerian Coastal Waters. Acta Botanica Hungarica, 53, 137-143. https://doi.org/10.1556/ABot.53.2011.1-2.12

[24] Nwankwo, D.I. (1997) A First List of Dinoflagellates (Pyrrhophyta) from Nigerian Coastal Waters (Creek, Estuaries Lagoons). Poliskie Archiwum Hydrobiologii, 44, 313-321.

[25] Zendong, S.Z., Kadiri, M., Herrenknecht, C., Nézan, E., Mazzeo, A. and Hess, P. (2016) Algal Toxin Profiles in Nigerian Coastal Waters (Gulf of Guinea) Using Passive Sampling and Liquid Chromatography Coupled to Mass Spectrometry. Toxicon, 114, 16-27. https://doi.org/10.1016/j.toxicon.2016.02.011

[26] Chattopadhyay, J., Sarkar, R.R. and Ghosal, G. (2002) Removal of Infected Prey Prevent Limit Cycle Oscillations in an Infected Prey-Predator System: A Mathe- 
matical Study. Journal of Ecological Modelling, 156, 113-121. https://doi.org/10.1016/S0304-3800(02)00133-3

[27] Pal, R., Basu, D. and Banerjee, M. (2009) Modelling of Phytoplankton Allelopathy with Monod-Haldane-Type Functional Response: A Mathematical Study. Biosystems, 95, 243-253. https://doi.org/10.1016/j.biosystems.2008.11.002

[28] Chakraborty, S., Roy, S. and Chattopadhyay, J. (2008) Nutrient-Limited Toxin Production and the Dynamics of Two Phytoplankton in Culture Media: A Mathematical Model. Ecological Modelling, 213, 191-201. https://doi.org/10.1016/j.ecolmodel.2007.12.008

[29] Blauw, A.N., Los, F.J., Huisman, J. and Peperzak, L. (2010) Nuisance Foam Events and Phaeocystis globosa Blooms in Dutch Coastal Waters Analyzed with Fuzzy Logic. Journal of Marine Systems, 83, 115-126. https://doi.org/10.1016/j.jmarsys.2010.05.003

[30] Anderson, C.R., Sapiano, M.R.P., Prasad, M.B.K., Long, W., Tango, P.J., Brown, C.W. and Murtugudde, R. (2010) Predicting Potentially Toxigenic Pseudo-nitzschia Blooms in the Chesapeake Bay. Journal of Marine Systems, 83, 127-140. https://doi.org/10.1016/j.jmarsys.2010.04.003

[31] Banerjee, M. and Venturino, E. (2011) A Phytoplankton-Toxic Phytoplankton-Zooplankton Model. Ecological Complexity, 8, 239-248. https://doi.org/10.1016/j.ecocom.2011.04.001

[32] Tomas, C.R. (1977) Identifying Marine Phytoplankton. Academic Press, St. Petersburg, $858 \mathrm{p}$.

[33] Botes, L. (2001) Phytoplankton Identification Catalogue-Saldanha Bay, South Africa. GloBallast Monograph Series No. 7, IMO, London, 88 p.

[34] Hoppenrath, M., Elbrächter, M. and Drebes, G. (2009) Marine Phytoplankton. Druckerei Hubert and Company, Göttingen, 264 p.

[35] Al-Kandari, M., Al-Yamani, F.Y. and Al-Rifaie, K. (2009) Marine Phytoplankton Atlas of Kuwait's Waters. Kuwait Institute for Scientific Research, Kuwait City, 351 p.

[36] Kraberg, A., Bauman, M. and Dürselen, C. (2010) Coastal Phytoplankton Photo Guide for Northern European Seas. Verlag, München, 204 p.

[37] Lackey, J.B. (1938) The Manipulating and Counting of River Plankton and Changes in Some Organisms Due to Formalin Preservation. U.S. Public Health Reports, 53, 343-345. https://doi.org/10.2307/4582717

[38] Tang, D.L., Kawamura, H., Dien T.V. and Lee, M.A. (2004) Offshore Phytoplankton Biomass Increase and Its Oceanographic Causes in the South China Sea. Marine Ecology Progress Series, 268, 31-41. https://doi.org/10.3354/meps268031

[39] Glibert, P.M. and Burkholder, J.M. (2006) The Complex Relationships between Increasing Fertilization of the Earth, Coastal Eutrophication, and HAB Proliferation. In: Granéli, E. and Turner, J., Eds., Ecology of Harmful Algae, Springer-Verlag, New York, 341-354. https://doi.org/10.1007/978-3-540-32210-8_26

[40] Paerl, H.S., Fulton, R.S., Moisander, P.H. and Dyble, J. (2001) Harmful Freshwater Algal Blooms with an Emphasis on Cyanobacteria. Scientific World Journal, 4, 76-113. https://doi.org/10.1100/tsw.2001.16

[41] Sellner, K.G., Doucette, G.J. and Kirkpatrick, G.J. (2003) Harmful Algal Blooms: Causes, Impacts and Detection. Journal of Industrial Microbiology and Biotechnology, 3, 383-406. https://doi.org/10.1007/s10295-003-0074-9

[42] Hodgkiss, I.J. and Lu, S.H. (2004) The Effect of Nutrients and Their Ratios on Phy- 
toplankton Abundance in Junk Bay, Hong Kong. Hydrobiologia, 512, 215-229. https://doi.org/10.1023/B:HYDR.0000020330.37366.e5

[43] Imai, I., Yamaguchi, M. and Hori, M. (2006) Eutrophication and Occurrences of Harmful Algal Blooms in the Seto Inland Sea, Japan. Plankton Benthos Research, 1, 71-84. https://doi.org/10.3800/pbr.1.71

[44] Heil, C.A., Glibert, P.M. and Fan, C.L. (2005) Prorocentrum minimum (Pavillard) Schiller: A Review of a Harmful Algal Bloom Species of Growing Worldwide Importance. Harmful Algae, 4, 449-470. https://doi.org/10.1016/j.hal.2004.08.003

[45] Wang, H.K., Huang, L.M., Huang, X.P., Song, X.Y., Wang, H.J., Wu, N.J. and Li, C. (2003) A Red Tide Caused by Gyrodinium instriatum and Its Environmental Characters in Zhujiang River Estuary. Journal of Tropical Oceanography, 22, 55-62.

[46] Qian, H.L. and Liang, S. (1999) Study on the Red Tide in the Pearl River Estuary and Its Near Waters. Marine Environmental Science, 18, 69-74.

[47] Graneli, E. and Flynn, K. (2006) Chemical and Physical Factors Influencing Toxin Content. In: Graneli, E. and Turner, J.T., Eds., Ecology of Harmful Algae, Springer-Verlag, New York, 229-241. https://doi.org/10.1007/978-3-540-32210-8_18

[48] Steidinger, K.A. and Garcces, E. (2006) Importance of Life Cycle History in the Ecology of Harmful Microalgae. In: Graneli, E. and Turner, J.T., Eds., Ecology of Harmful Algae, Springer-Verlag, Berlin, Chap. 4, Volume 189, 37-49. https://doi.org/10.1007/978-3-540-32210-8_4

[49] Takeda, S. (1998) Influence of Iron Availability on Nutrient Consumption Ratio of Diatoms in Oceanic Waters. Nature, 393, 774-777. https://doi.org/10.1038/31674 